\title{
Comparative analysis of the production risk of major fruit species
}

\author{
Persely, Sz. \\ University of Debrecen, Centre for Agricultural Sciences and Engineering, \\ Department of Economic Analysis and Statistics, H-4032 Debrecen, 138 Böszörményi, Hungary
}

\begin{abstract}
Summary: Hungary possesses excellent agri-ecological potentials even in an international comparison. Despite their decreasing economic weight, agriculture and food production are of great significance, since the supply of the population with high quality and inexpensive food is a fundamental social demand and one of the essentials of the quality of life. The development of vegetable and food production is of great importance both from the aspect of healthy nutrition and comparative advantages (cheap workforce, professional expertise, traditions of production, climate favourable for quality). Within the Hungarian fruit production apple and sour cherry are essential branches in virtue of their significance. It is widely known, that - though to a different extent in the case of certain fruit varieties - satisfaction of the need for appropriate habitat is one of the important conditions of a decent quality and secure production. In my research, I analyse the territorial distribution, production standard and production risk of the Hungarian apple and sour cherry branches. I did not have the opportunity because of the imperfections of the database - to compare long time series, therefore I examine the random effects affecting production by using the data of 3 years (they have the same content). I ranked and assessed each habitat and the production risks of certain fruit species compared to each other on the basis of indexes of relative deviation.
\end{abstract}

Key words: apple, sour cherry, production risk, regions

\section{Introduction}

The growing traditions and the favourable agroecological conditions of Hungary and the requirements of healthy nutrition all call for the development of the fruit production sector and for the establishment of competitive production conditions. The rethinking of the future of the sector - under strong European competition conditions - should start with the analysis of the current situation and with the study of the harmony between the fruit species and the growing sites.

Our international competitiveness depends on numerous factors such as growing site conditions enabling high quality, high productivity per unit area, cheap labour, expertise and growing traditions, cultivation method adapted to the composition of inputs and their costs, appropriate concentration and organization of production, high-level packaging of the product and a good representation of interests via cooperation (Ertsey, 1990; Bagoly et al., 1993; Balázs \& Inántsy, 2004; Bernáth et al., 2006; Csepregi et al., 1996; Dénes et al., 2001; Ertsey \& Drimba, 2003). In my study, I analyse the territorial distribution, production level and production risks of two fruit species - apple and sour cherry - of great importance in Hungarian fruit production. The total area of Hungary is only 93 thousand $\mathrm{km}^{2}$, on which all the crops requiring continental climate conditions can be successfully grown, however, due to the differing precipitation conditions, soil quality and weather extremes (frost, hail), well-defined growing districts were formed for the species requiring special growing site conditions.

\section{Materials and methods}

\section{Apple production}

Yields and relative deviations of apple production are presented in Table 1 and Table 2 according to regions. Yields presented are the averages of yields in 2003, 2004 and 2005. Due to the deficiencies in the database, I was not able to compare long time series, therefore, the random effects of production are studied using the data of three years as they have the same content. Based on the indices of relative deviation, the growing sites can be ranked according to production risks. In Table 1, it can be seen that Hungarian apple production has a low production level and there are significant differences among the regions. The level of production is the highest in Central Transdanubia and the lowest in South Transdanubia. Regarding the risks of

Table 1: Level of apple production in the different regions

\begin{tabular}{|l|c|}
\hline \multicolumn{1}{|c|}{ Regions } & Average (t/ha) \\
\hline Central Transdanubia & 16,79 \\
\hline West Transdanubia & 15,12 \\
\hline Central Hungary & 14,64 \\
\hline South Great Plain & 14,18 \\
\hline North Great Plain & 13,07 \\
\hline North Hungary & 11,51 \\
\hline South Transdanubia & 11,36 \\
\hline
\end{tabular}

Source: CSO (Central Statistical Office) 
production (Table 2), the least favourable is the Northern Great Plain region which has the oldest growing traditions and is the largest apple growing district. The most favourable region in this respect is the West Transdanubian region, where the relative yield fluctuation is only 6.3\%. Studying the causes in both regions - considering the limitations of the available database - I analyse the concentration of production and the differences in the age and cultivation methods of the orchards.

Table 2: Relative deviations of apple production in the different regions

\begin{tabular}{|l|c|}
\hline \multicolumn{1}{|c|}{ Regions } & V $(\%)$ \\
\hline North Great Plain & 22,00 \\
\hline Central Hungary & 17,82 \\
\hline South Transdanubia & 17,05 \\
\hline Central Transdanubia & 15,28 \\
\hline South Great Plain & 12,28 \\
\hline North Hungary & 11,07 \\
\hline West Transdanubia & 6,27 \\
\hline
\end{tabular}

Source: CSO (Central Statistical Office)

The concentration of apple orchards in the West Transdanubian region and the Northern Great Plain region is demonstrated in Figure 1 and Figure 2, respectively. It can be stated that production is more concentrated in the Northern Great Plain region, since the ratio of orchards larger than 25 ha is $27 \%$ here, while it is $19 \%$ in West Transdanubia. There are great differences between the two regions in the categories of 15-19.9 ha and 20-24.9 ha in favour of the West Transdanubian region with values of $14 \%$ and $11 \%$ as opposed to only $8 \%$ and $6 \%$ in the Northern Great Plain region.

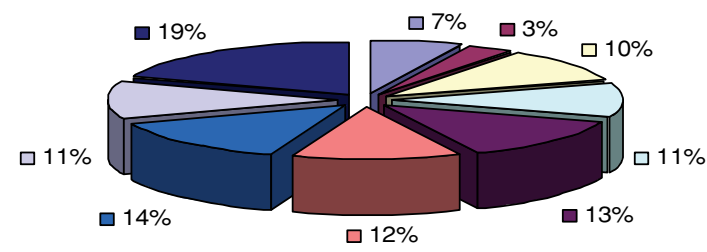

\begin{tabular}{|c|c|c|}
\hline 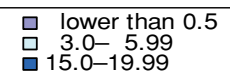 & $\begin{array}{l}0.5-0.99 \\
6.0-9.99 \\
\square 20.0-24.99\end{array}$ & $\begin{array}{l}\square \\
\square \\
\square 10.0-14.99 \\
\square 25 \text { and higher }\end{array}$ \\
\hline
\end{tabular}

Source: Own figure based on CSO data

Figure 1: Distribution of apple orchards in West Transdanubia according to size
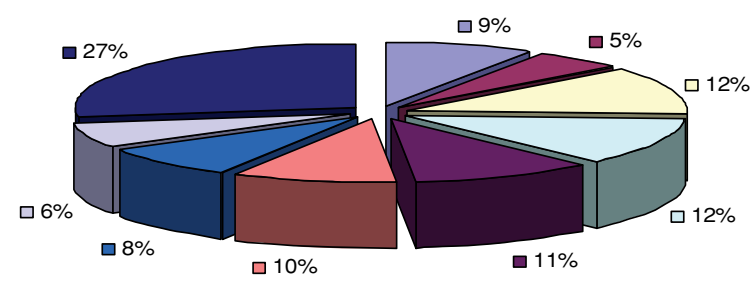

\begin{tabular}{|c|c|c|}
\hline $\begin{array}{l}\square \quad \text { lower than } 0.5 \\
3.0-5.99 \\
\square 15.0-19.99\end{array}$ & $\begin{array}{r}0.5-0.99 \\
6.0-9.99 \\
\square 20.0-24.99\end{array}$ & 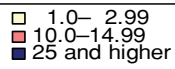 \\
\hline
\end{tabular}

Source: Own figure based on CSO data

Figure 2: Distribution of apple orchards in the Northern Great Plain according to size
The age of the orchards partly explains the regional differences and similarities in concentration. The plantings between 1997 and 2001 have a similar ratio in both regions. The ratio of the oldest orchards is $45 \%$ and $38 \%$ in the Northern Great Plain region and West Transdanubia, respectively. The ratio of orchards established in the periods of 1977-1986 and 1987-1991 is 5\% and 4\% higher in the Northern Great Plain than in West Transdanubia. The differences between the regions in the level of production can be explained mainly by the different age structure. The ratio of orchards older than 20 years is $68 \%$ in the Northern Great Plain and 52\% in West Transdanubia. After the change of the regime - in the period of 1992-1996 - the ratio of orchards planted was $30 \%$ in West Transdanubia - there a more intensive modern development started -, while it was only $13 \%$ in the Northern Great Plain.

The cultivation method can be regarded as an indication of the modernity of the orchard as the cultivation methods differ in rootstock, tree spacing, fruit-bearing capacity, labour productivity. In Figure 5, it can be seen that the structure of orchards is not only younger in West Transdanubia, but also more modern, since the ratio of traditional cultivation is only $13 \%$ as opposed to $49 \%$ in the Northern Great Plain region. The ratio of thin spindle form is $35 \%$ in West Transdanubia, while it is only $7 \%$ in the Northern Great Plain region. The ratio of hedge plantings in West Transdanubia is double of that in the growing district with the highest risk.

In sum, based on the analysis, it can be stated that the production risks are smaller in the younger, modern orchards and that the large differences in production risks between the two regions is partly due to the different age structure and the different cultivation methods of the orchards.

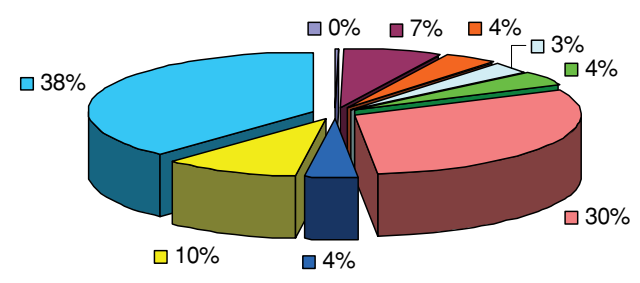

\begin{tabular}{|lll|}
\hline 2001 & $\square 2000$ & \\
$\square 1998$ & $\square 1997-1999$ \\
$\square 1987-1991$ & $\square 1977-1986$ & $\square 1992-1996$ \\
& $\square 1976$ and before \\
\hline
\end{tabular}

Source: Own figure based on CSO data

Figure 3: Times of the establishment of apple orchards in West Transdanubia

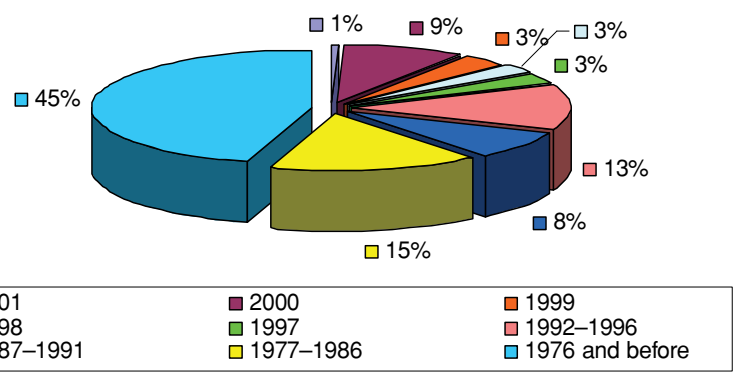

Figure 4: Times of the establishment of apple orchards in the Northern Great Plain 

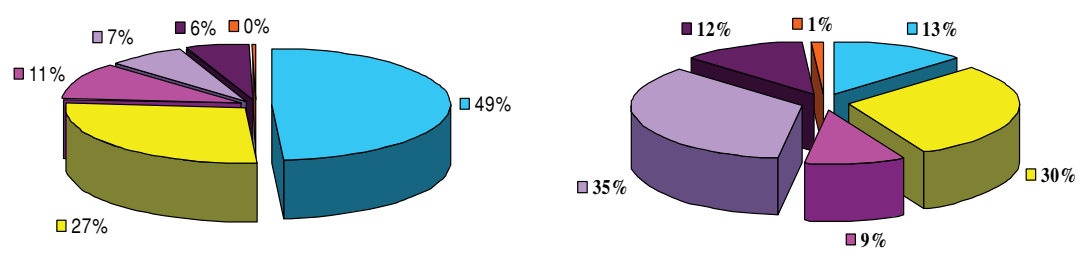

Source: Own figure based on CSO data

$\square$ traditional $\square$ producing branch $\square$ free spindle $\square$ thin spindle $\square$ hedge $\square$ other

Figure 5: The cultivation methods of apple orchards in West Transdanubia and the Northern Great Plain

\section{Sour cherry production}

In Table 3 and Table 4, similarly to the other fruit species, the specific yields and the production risks of sour cherry production are presented per region.

The level of production is the highest in the South Transdanubian region and there are great differences among the regions. Yields in the Northern Great Plain region - the major sour cherry growing district - and in West Transdanubia are less than half of those in South Transdanubia. The second largest growing district is the

Table 3: The level of sour cherry production per region

\begin{tabular}{|l|c|}
\hline \multicolumn{1}{|c|}{ Regions } & Average (t/ha) \\
\hline South Transdanubia & 6,21 \\
\hline North Hungary & 5,81 \\
\hline Central Transdanubia & 5,74 \\
\hline South Great Plain & 4,10 \\
\hline North Great Plain & 2,93 \\
\hline West Transdanubia & 2,90 \\
\hline Central Hungary & 1,81 \\
\hline
\end{tabular}

Source: CSO

Table 4: Relative deviation of sour cherry production per region

\begin{tabular}{|l|c|}
\hline \multicolumn{1}{|c|}{ Regions } & V $(\%)$ \\
\hline North Hungary & 73,26 \\
\hline North Great Plain & 24,66 \\
\hline Central Hungary & 19,89 \\
\hline South Great Plain & 18,29 \\
\hline West Transdanubia & 10,02 \\
\hline Central Transdanubia & 8,74 \\
\hline South Transdanubia & 7,20 \\
\hline
\end{tabular}

Source: CSO

region of Northern Hungary, the yields of which are relatively high but the production risks are extremely high (73\%), which means extreme yield fluctuation and is due to climate conditions. In spite of its low yields, the Northern Great Plain region is second in the rank regarding the risks, but the safest growing district is South Transdanubia. The distribution of sour cherry orchards in South Transdanubia and the Northern Great Plain according to size is presented in Figures 6 and 7, respectively.
Regarding the concentration in production above 20 ha, there is not a great difference between the two regions, while the ratio of orchards larger than 10 ha is $62 \%$ in South Transdanubia, it is $63 \%$ in the Northern Great Plain region.

Regarding the age structure of orchards, there are large differences between the two regions as is presented in Figure 8 and 9. The ratio of orchards established before 1980 is $30 \%$ in South Transdanubia, while it is only $11 \%$ in Northern Hungary. In Northern Hungary, $74 \%$ of the orchards were established after 1995 , while the same ratio is only $42 \%$ in South Transdanubia.

There are also great differences between the two regions in the cultivation methods in parallel with the differences in age structure. The orchards are more modern in Northern
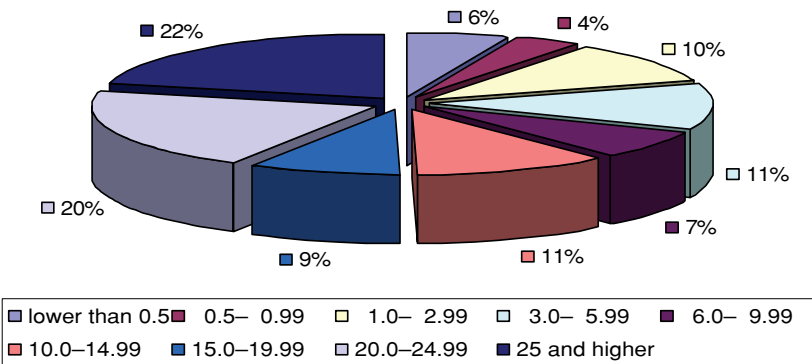

Source: Own figure based on CSO data

Figure 6: Distribution of sour cherry orchards in South Transdanubia according to size
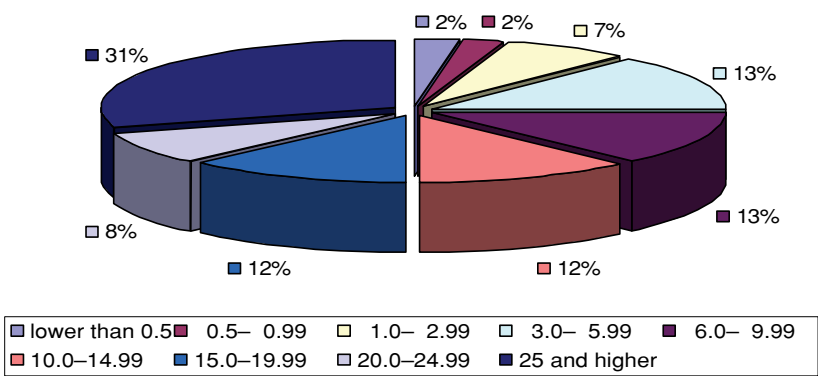

Source: Own figure based on CSO data

Figure 7: Distribution of sour cherry orchards in Northern Hungary according to size

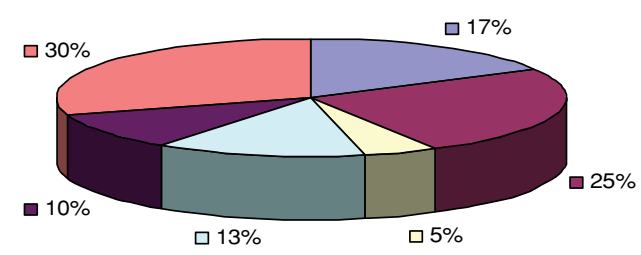

\begin{tabular}{|lll|}
\hline$\square 2000$ and after & $\square 1995-1999$ & $\square 1990-1994$ \\
$\square 1985-1989$ & $\square 1981-1984$ & $\square 1980$ and before \\
\hline
\end{tabular}

Source: Own figure based on CSO data

Figure 8: Times of establishment of sour cherry orchards in South Transdanubia 
Hungary, the ratio of traditional orchards is $44 \%$, while in South Transdanubia it is $61 \%$.

In sum, it can be stated that the South Transdanubian region is a traditional, relatively small sour cherry growing district with relatively high production level and low production risks. The age structure and cultivation type of orchards do not explain the production risks, these are mainly due to the growing site conditions.

\section{Conclusion}

In Figure 11, the degree of risks per growing district is presented for each fruit species. For all two fruit species, there are great differences among the regions regarding production risks.

The regional differences are relatively lower for apple, the production risks are almost the same in Central Hungary, Central Transdanubia and South Transdanubia, Southern Great Plain regions. The risks are high in the Northern Great Plain and the most favourable is the West Transdanubian region. The risks of sour cherry production are very high in Northern Hungary and are higher than that of the other two fruit species in Central Hungary and the Northern and Southern Great Plain regions. However, it can be relatively safely grown in Central Transdanubia and South Transdanubia.

\section{Acknowledgements}

Herewith I would like to express our gratitude to Ertsey Imre, Nyéki József and Szabó Zoltán for the inspiration and assistance, and to the Research Projects: OTKA K63065/2006, OM-00042/2008, OM-00265/2008, OM-00270/2008 for the subventions.

\section{References}

Bagoly L., Deák, I., Főző, J. \& Keszei, A. (1993): Gyümölcstermesztés I., Agrárszakoktatási Intézet, Budapest

Balázs, K. \& Inántsy, F. (eds) (2004): Integrált növénytermesztés. Alma. Agroinform Kiadó, Budapest

Bernáth, J., Botos, E., Erdész, F., Gerzson, L., Hajdu, E., Holb, I., Kováts, Z., Kristóf, L., Lakatos, L., Nyéki, J., Racskó, J., Schmidt, G., Slezák, K., Soltész, M., Szabó, Z., Terbe, I., Thurzó, S. \& Tökei, L. (2006): Klímaváltozás és a magyarországi kertgazdaság, Bp., „AGRO-21” Kutatási Programiroda

Csepregi, T., Farkasné, K. SZ., Kállay, T., Mérö, F., Török, Z., Inántsy, F., Makai, P., Pethő, F., Thurn, L., Zatykó, I. \& Zajácz, G. (1996): Gyümölcs-zöldségkereskedelem a gyakorlatban. Alma. Almatermesztők Szövetsége, Debrecen

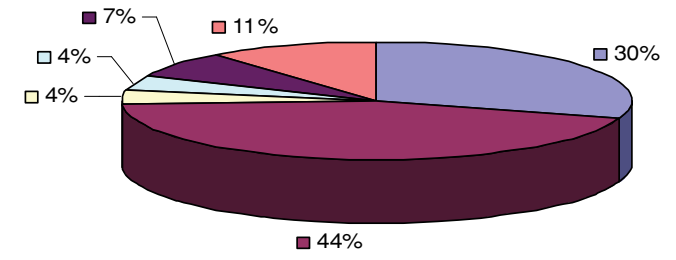

\begin{tabular}{|lll|}
\hline$\square 2000$ and after & $\square$ 1995-1999 & $\square 1990-1994$ \\
$\square 1985-1989$ & $\square 1981-1984$ & $\square 1980$ and before \\
\hline
\end{tabular}

Source: Own figure based on CSO data

Figure 9: Times of establishment of sour cherry orchards in Northern Hungary
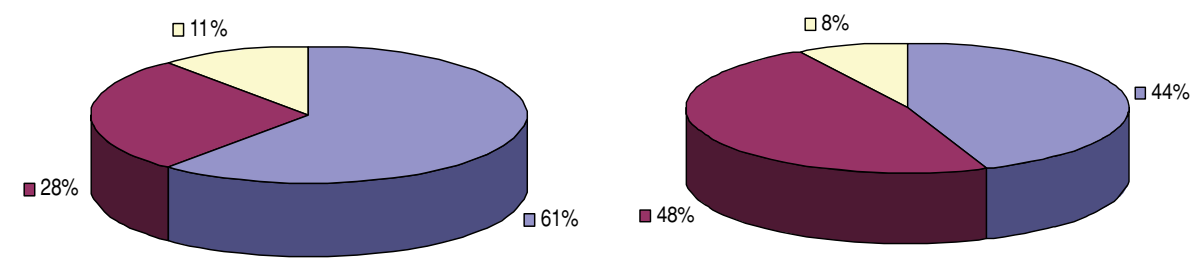

$\square$ traditional $\square$ vase $\square$ other

Source: Own figure based on CSO data

Figure 10: The cultivation methods in sour cherry orchards in South Transdanubia and Northern Hungary

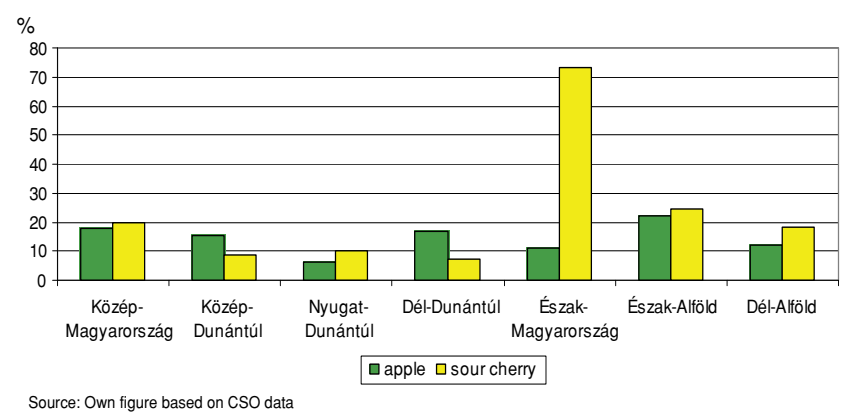

Figure 11: Relative deviations per fruit species and growing districts

Dénes, F., Göndör, J.-né, Tóth, M. G. \& Szabó, T. (2001): Almatermésűek és bogyósok, Mezőgazda Kiadó, Budapest

Ertsey I. \& Drimba P. (2003): A kukorica terméseredményeinek elemzése a műtrágyázás függvényében, a kockázat figyelembevételével. (In: Nagy János (eds.): Kukorica-hibridek adaptációs képességének és termésbiztonságának javítása.) Civis-Copy Kft., Debrecen, 149-163. p.

Ertsey, I. (1990): A kockázat mérésének módszertani kérdései a növénytermesztésben. Tisztántúli Mezőgazdasági Tudományos Napok, Debrecen

Nyéki, J., Soltész, M. \& Szabó, T. (2008): Meggyültetvények létesítése és termesztéstechnológiája. Debreceni Egyetem AMTC, KFI. 99 p.

Soltész, M. \& Holb, I. (2007): Integrált növényvédelem a csonthéjasok ültetvényeiben. (In: Nyéki J., Soltész M., Szabó Z. (szerk.) Ökológiai szemléletű integrált gyümölcstermesztés (csonthéjasok).) Pixelgraf Bt. Kecskemét, 2007. pp. 58-69.

Soltész, M., Nyéki, J. \& Szabó, Z. (2004): A klímaváltozás kihívásai a gyümölcstermesztésben. „AGRO-21” Füzetek 34: 3-20. Tóth, M. G. (2001): Gyümölcsészet, Primom Vállalkozásélénkítő Alapítvány, Nyíregyháza 